\title{
PENGARUH RETURN ON EQUITY (ROE) DAN PRICE EARNING RATIO (PER) TERHADAP HARGA SAHAM PERUSAHAAN MANUFAKTUR SUB SEKTOR FARMASI DI BURSA EFEK INDONESIA
}

\author{
Mariyam Zanariah ${ }^{1)}$, Azmir Ferdinansyah ${ }^{2)}$ \\ 1,2, Dosen jurusan manajemen, Universitas Tridinanti, Palembang, Sumatera Selatan, Indonesia \\ 1) mariyam0222096301@gmail.com, 2) azmir0221105801@gmail.com
}

\begin{tabular}{l} 
INFORMASI ARTIKEL \\
\hline Submitted: \\
15/12/2021 \\
Revised: \\
20/12/2021 \\
Accepted: \\
25/12/2021 \\
Online-Published: \\
31/12/2021
\end{tabular}

\section{A. PENDAHULUAN}

PandemiCOVID-19 yang terjadi mulai awal tahun 2020 menjadikan kebutuhanakan vitamin, suplemen dan obat herbal untuk meningkatkan daya tahan tubuh secara umum meningkat, sehingga industri farmasi yang bermain di sektor tersebut memperoleh pertumbuhan yang cukup besar yaitu pertumbuhan positif sejak tahun 2019, bahkan mengalami kenaikan pertumbuhan pada2020 menjadi $9,39 \%$ dari sebesar $8,48 \%$ pada tahun 2019. Industri farmasi juga masih sangat berpotensi untuk dikembangkan,mengingat besarnya pasar domestik di Indonesia, dan jug auntuk peningkatan ekspor produk-produk farmasi.

Perkembangan Industri Farmasi di Saat Pandemi Covid-19 sebenarnya menciptakan peluang untuk mendorong produksi farmasi dalam negeri. Namun akibat 
ketergantungannya pada bahan baku impor yang sekitar 60 persennya diimpor dari Cina, maka pandemi Covid 19 justru menurunkan produksi industri farmasi Indonesia hingga 60 persen di bulan Mei2020.

Hal ini yang mendorong setiap perusahaan farmasi harus mampu memanfaatkan peluang dan kemampuan yang mereka miliki agar dapat bersaing dengan perusahaan-perusahaan lain dan juga untuk menghindari adanya potensi kebangkrutan. Pasar modal merupakan suatu sarana yang dapat dimanfaatkan oleh perusahaan untuk pengembangan usaha, ekspansi, dan penambahan modal kerja. Salah satu caranya ialah dengan menjual saham perusahaan di bursa efek yang lebih dikenal dengan go public.

Harga saham merupakan salah satu indikator keberhasilan pengelolaan perusahaan, jika harga saham suatu perusahaan mengalami kenaikan maka investor atau calon investor menilai bahwa perusahaan berhasil dalam mengelola usahanya (Zuliarni, 2012 : 1). Semakin banyak permintaan terhadap saham suatu perusahaan maka dapat menaikkan harga saham tersebut. Jika harga saham yang tinggi dapat dipertahankan maka kepercayaan investor terhadap perusahaan juga semakin tinggi dan hal ini juga akan menaikkan nilai perusahaan. Sebaliknya, jika harga saham mengalami penurunan secara terus - menerus berarti dapat menurunkan nilai perusahaan dimata investor.

Perubahan harga saham sangat ditentukan oleh kekuatan permintaan dan penawaran investor yang terjadi di pasar sekunder. Keputusan investor dalam melakukan transaksi jual beli saham dipengaruhi oleh faktor mikro maupun makro perusahaan. Faktor mikro merupakan faktor internal perusahaan yang mempengaruhi transaksi perdagangan saham, antara lain harga saham, tingkat keuntungan yang diperoleh, tingkat risiko, kinerja perusahaan, dan corporate action yang dilakukan perusahaan tersebut. Sedangkan faktor makro merupakan faktor eksternal perusahaan, antara lain tingkat perkembangan inflasi, kurs rupiah, keadaan perekonomian dan kondisi sosial politik negara.
Investasi dalam saham selain menjanjikan tingkat keuntungan yang tinggi, juga mengandung tingkat risiko yang tinggi pula. Investor akan selalu mengharapkan mendapat keuntungan yang memadai dengan tingkat risiko yang rendah dari investasi yang dilakukan. Dalam keadaan yang sebenarnya semua investasi mengandung ketidakpastian atau risiko. Risiko dalam suatu investasi saham dapat dikurangi dengan dibutuhkannya informasi yang akurat, aktual dan transparan mengenai perusahaan (Setiawan, 2009). Laporan keuangan perusahaan merupakan sumber informasi yang dibutuhkan dan sangat penting karena memberikan informasi yang bisa dipakai untuk pemgambilan keputusan. Informasi tersebut akan mempengaruhi harapan dari pihak-pihak yang berkepentingan dan pada giliran selanjutnya akan mempengaruhi nilai perusahaan. Analisis rasio merupakan salah satu teknik analisis fundamental yang digunakan untuk membantu menganalisis laporan keuangan perusahaan sehingga dapat diketahui kekuatan dan kelemahan suatu perusahaan. Analisis rasio menyediakan indikator yang dapat mengukur tingkat likuiditas, leverage, aktivitas maupun profitabilitas suatu perusahaan (Munawir, 2014).

Rasio profitabilitas merupakan rasio untuk menilai kemampuan perusahaan dalam mencari keuntungan. Rasio ini juga memberikan ukuran tingkat efektivitas manajemen suatu perusahaan. Hal ini ditunjukkan oleh laba yang dihasilkan dari penjualan dan pendapatan investasi (Kasmir,2018:196). Semakin tinggi tingkat profitabilitas, maka semakin baik kelangsungan hidup suatu perusahaan. Hal ini ditunjukkan dengan laba yang meningkat, sehingga dapat menarik minat para investor untuk berinvestasi diperusahaan tersebut. Rasio profitabilitas yang digunakan dalam penelitian ini yaitu Return on Equity (ROE) yang merupakan salah satu rasio yang mengukur perbandingan antara laba bersih setelah pajak terhadap modal sendiri. Teori profitabilitas diukur dengan Return on Equity (ROE) menurut Tandelilin (2010:315), semakin tinggi $R O E$ berarti semakin baik kinerja perusahaan dalam mengelola modalnya untuk menghasilkan keuntungan 
(return) bagi para pemegang saham secara efektif dan efisien untuk memperoleh laba.

Hasil penelitian Astrid Amanda, (2013) menunjukkan bahwa variabel Return on Equity (ROE) berpengaruh positif dan signifikan terhadap harga saham. Namun, berbeda dengan Muhammad Ircham, (2014) yang menunjukkan bahwa Return on Equity (ROE) berpengaruh negatif dan signifikan terhadap harga saham.

Rasio nilai pasar menggambarkan kondisi yang terjadi di pasar. Rasio ini mampu memberi pemahaman bagi pihak manajemen perusahaan terhadap kondisi penerapan yang akan dilaksanakan dan dampaknya pada masa yang akan datang ( Irham Fahmi, 2012:138). Dalam penelitian ini rasio pasar yang digunakan adalah Price Earning Ratio (PER). PER mengukur perbandingan antara harga pasar per lembar saham (market price pershare) dengan laba per lembar saham (earning pershare). Teori pengaruh nilai pasar yang diukur dengan Price Earning Ratio (PER), menurut Irham Fahmi (2012:138) menyatakan bahwa "bagi para investor semakin tinggi Price Earning Ratio (PER) maka pertumbuhan laba yang diharapkan semakin besar dan juga akan mengalami kenaikan terhadap harga saham".

Hasil penelitian Rini Puspitasari (2013), menyatakan bahwa PER secara parsial berpengaruh positif terhadap harga saham. Berbeda dengan hasil penelitian Teska Destia Ratri (2015) bahwa PER tidak berpengaruh terhadap harga saham.

Berdasarkan dari latar belakang tersebut, maka dapat dirumuskan permasalahan sebagai berikut:

1. Apakah Return On Equity (ROE) secara parsial berpengaruh terhadap perubahan harga saham Perusahaan Manufaktur sub sektor Farmasi di Bursa Efek Indonesia ?

2. Apakah Price Earning Ratio (PER) secara parsial berpengaruh terhadap perubahan harga saham sPerusahaan Manufaktur ub sektor Farmasi di Bursa Efek Indonesia ?

3. Apakah Return On Equity (ROE) dan Price Earning Ratio (PER) secara simultan berpengaruh terhadap harga saham Perusahaan Manufaktur sub sektor Farmasi di Bursa Efek Indonesia?
Sesuai dengan permasalahan yang diajukan dalam penelitian, maka tujuan dalam penelitian ini adalah:

1. Untuk mengetahui apakah Return On Equity (ROE) berpengaruh secara parsial terhadap harga saham Perusahaan Manufaktur sub sektor Farmasi di Bursa Efek Indonesia .

2. Untuk mengetahui apakah Price Earning Ratio (PER) berpengaruh secara parsial terhadap harga saham Perusahaan Manufaktur sub sektor Farmasi di Bursa Efek Indonesia .

3. Untuk mengetahui apakah Return On Equity (ROE) dan Price Earning Ratio $(P E R)$ secara simultan berpengaruh terhadap harga saham Perusahaan Manufaktur sub sektor Farmasi di Bursa Efek Indonesia .

\section{B. METODE PENELITIAN}

\section{a. Populasi dan Sampel}

Menurut Sugiyono (2014:72), "Populasi adalah wilayah generalisasi yang terdiri atas objek atau subjek yang mempunyai kualitas dan karakteristik tertentu yang ditetapkan oleh peneliti untuk dipelajari dan kemudian ditarik kesimpulannya."

Populasi dalam penelitian ini merupakan Perusahaan Manufaktur Sub Sektor Farmasiyang terdaftar di Bursa Efek Indonesia (BEI) Tahun 2021 sebanyak 12 perusahaan .

Teknik pengambilan sampel dalam penelitian ini adalah purposive sampling, yaitu dengan menetapkan beberapa kriteria untuk menyaring populasi menjadi sampel. Sampel dipilih dengan beberapa kriteria sebagai berikut:

a. Perusahaan Farmasi yang terdaftar di BEI yang mempunyai laporan keuangan paling lengkap dan telah dipublikasikan dari tahun 2015- 2018.

b. Perusahaan memiliki data yang lengkap mengenai variabel-variabel yang digunakan dalam penelitian.

c. Mempublikasikan harga saham dari tahun 2015 - 2018.

d. Sampel tidak pindah sub sektor selama tahun pengumpulan data. 
e. Sampel tidak mengalami delisting maupun baru melakukan penawaran perdana selama tahun pengumpulan data.

Berdasarkan kriteria tersebut, maka diperoleh jumlah sampel perusahaan manuftur sub sektor Farmasi sebanyak 8perusahaan periode tahun 2015-2018. Berikut nama-nama perusahaan manufaktur sub sektor Farmasi yang dijadikan sebagai sampel dalam penelitian ini.

Tabel 1. Daftar Sampel Perusahaan Manufaktur Sub Sektor Farmasi Di BEI Tahun 2015-2018

\begin{tabular}{|l|l|l|}
\hline No. & Kode & \multicolumn{1}{|c|}{ Nama Perusahaan } \\
\hline 1 & DVLA & Darya-Varia Laboratoria \\
\hline 2 & KAEF & Kimia Farma \\
\hline 3 & KLBF & Kalbe Farma \\
\hline 4 & MERK & Merck \\
\hline 5 & PYFA & Pyridam Farma \\
\hline 6 & SIDO & Sido Muncul \\
\hline 7 & TSPC & Tempo Scan Pacific \\
\hline 8 & SDPC & Millenium Pharmacon International \\
\hline
\end{tabular}

Sumber: Bursa Efek Indonesia

(www.idx.co.id),2021

\section{b. Rancangan Penelitian}

Rancangan penelitian merupakan suatu rencana, struktur dan strategi penelitian yang dimaksudkan untuk memberikan jawaban terhadap permasalahan yang dihadapi. Dalam penyusunan penelitian ini menggunakan pendekatan asosiatif dimana tujuannya adalah untuk mengetahui pengaruh ataupun hubungan antara dua variabel atau lebih. Dengan menggunaan data kuantitatif yang disusun berdasarkan laporan keuangan 8 perusahaan manufaktur sub sektor farmasi di Bursa Efek Indonesia (BEI) periode 20152018. Sumber data yang digunakan yaitu data sekunder berupa annual report yang diperoleh dari website Bursa Efek Indonesia yaitu www.idx.co.id.

Pada penelitian ini teknik analisis data yang dilakukan dengan menggunakan teknikanalisis regresi linear berganda untuk mengolah dan membahas data yang telah diperoleh dan untuk menguji hipotesis yang diajukan. Teknik ini dipilih karena untuk memperoleh gambaran yang menyeluruh mengenai hubungan antara variabel satu dengan variabel lain.

\section{c. Definisi Operasional Variabel Penelitian}

Menurut Sugiyono (2014:61) definisi operasional adalah penentuan konstrak atau sifat yang akan dipelajari sehingga menjadi variabel yang dapat diukur. Definisi operasional merupakan petunjuk tentang bagaimana suatu variabel di ukur, sehingga peneliti dapat mengetahui baik buruknya pengukuran tersebut. Adapun definisi operasional dalam penelitian ini adalah :

1. Return On Equity ( $\mathrm{X}_{1}$ )

Rasio ini digunakan untuk mengukur laba bersih setelah pajak dengan modal sendiri.

Rasio ini menunjukkan efisiensi penggunaan modal sendiri.

Rumus Return On Equity ( ROE ) :

\section{$\frac{\text { Earning After Interest and Tax }}{\text { Equity }} \times \mathbf{1 0 0 \%}$}

$\mathrm{ROE}=$

\section{Price Earning Ratio $\left(\mathrm{X}_{2}\right)$}

Rasio ini membandingkan antara harga saham dengan pendapatan setiap lembar saham dan merupakan indikator perkembangan atau pertumbuhan perusahaan di masa yang akan datang.

Rumus Price Earning Ratio ( PER ):

$$
\frac{\text { Earning Pershare }}{\mathrm{M}} \times 100 \%
$$

3. Harga Saham ( Y )

Harga saham yang dimaksud dalam penelitian ini adalah harga saham pada penutupan akhir (closing price) tiap perusahaan yang diperoleh dari harga saham penutupan akhir tahun per 31 Desember dengan periode tahun 2015 2018 pada perusahaan manufaktur sub sektor farmasi di Bursa Efek Indonesia .

\section{d. Teknik Analisis Data}

Analisis data bertujuan untuk menjawab permasalahan yang ada dalam penelitian. Teknik analisis data yang digunakan dalam penelitian ini adalah analisis statistik deskriptif dan analisis regresi linear berganda 
dengan bantuan program komputer SPSS 25. Untuk mencapai tujuan dalam penelitian ini, maka sebelum melakukan hipotesis dengan analisis regresi linear berganda terlebih dahulu dilakukan uji lolos kendala linier atau uji asumsi klasik untuk memastikan apakah model regresi linier berganda yang digunakan tidak terdapat masalah normalitas, multikolinieritas, heteroskedastisitas dan autokorelasi. Jika semua itu terpenuhi berarti bahwa model analisis telah layak digunakan.

Analisis regresi berganda dalam penelitian ini digunakan untuk mengetahui pengaruh $R O E$ $\left(\mathrm{X}_{1}\right)$ dan PER $\left(\mathrm{X}_{2}\right)$ terhadap harga saham ( $\mathrm{Y}$ ) Perusahaan Manufaktur sub sektor Farmasi di Bursa Efek Indonesia (BEI).

Persamaan regresi linier berganda adalah sebagai berikut :

$$
Y=\alpha+\beta_{1} X_{1}+\beta_{2} X_{2}+e
$$

Keterangan :

$\mathrm{Y}=$ Harga Saham

$\alpha=$ Konstanta

$\beta=$ Koefisien Regresi

$\mathrm{X}_{1} \quad=$ Return On Equity ( ROE )

$\mathrm{X}_{2} \quad=$ Price Earning Ratio (PER)

$\mathrm{E} \quad=$ Residual

\section{HASIL DAN PEMBAHASAN}

1. Hasil Uji Asumsi Klasik

Uji asumsi klasik digunakan untuk menguji apakah data penelitian yang akan digunakan memenuhi persyaratan regresi. Dalam penelitian ini digunakan pengujian berupa uji normalitas, multikolonieritas, heteroskedastisitas dan autokorelasi. Adapun uji asumsi klasik dapat diuraikan sebagai berikut:

a. Hasil Uji Normalitas

Uji normalitas data atau normal probability plots menunjukkan apakah residual terdistribusi secara normal atau tidak. Hasil uji normalitas dapat dilihat pada gambar 1 dibawah ini :

\section{Gambar 1. Hasil Uji Normalitas}

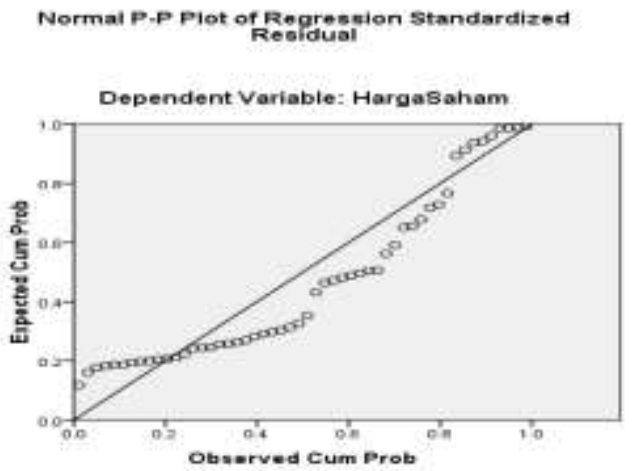

Berdasarkan hasil gambar diatas, menunjukkan titik-titik menyebar disekitar garis diagonal dan mengikuti arah garis diagonal. Sehingga, dapat disimpulkan bahwa residual terdistribusi secara normal dan model regresi yang digunakan layak dipakai karena telah memenuhi asumsi normalitas.

\section{b. Hasil Uji Multikolonieritas}

Menurut "Ghozali (2013:103-104), uji multikolonieritas bertujuan untuk menguji apakah model regresi ditemukan adanya korelasi antar variabel bebas (independen)". Metode yang digunakan untuk menguji ada atau tidaknya multikolonieritas dapat dilihat dari nilai Tolerance dan Variance Inflation Factor (VIF). Jika nilai Tolerance $>0,10$ dan nilai $V I F<10$ maka model dapat dikatakan terbebas dari multikolonieritas dan dapat digunakan dalam penelitian. Hasil uji multikolonieritas pada penelitian ini dapat dilihat pada tabel berikut

\section{Tabel 2. Hasil Uji Multikolonieritas}

\begin{tabular}{|l|l|r|c|}
\hline \multicolumn{3}{|c|}{ Coefficients $^{\text {a }}$} \\
\hline \multirow{2}{*}{\multicolumn{1}{|c|}{ Model }} & \multicolumn{2}{c|}{ Collinearity Statistics } \\
\cline { 3 - 4 } 1 & Tolerance & VIF \\
\hline \multirow{2}{*}{1} & ROE &, 968 & 1,033 \\
\cline { 2 - 4 } & PER &, 968 & 1,033 \\
\hline
\end{tabular}

a. Dependent Variable: HARGA SAHAM

Berdasarkan tabel 2 tersebut menunjukkan bahwa masing-masing variabel independen memiliki nilai tolerance $>0,10$ dan nilai $V I F<10$. Dengan demikian, dapat 
disimpulkan bahwa semua variabel independen dalam penelitian ini tidak terjadi multikolonieritas.

\section{c. Hasil Uji Heteroskedastisitas}

Menurut Ghozali (2013:134), uji heteroskedastisitas bertujuan menguji apakah dalam model regresi terjadi ketidaksamaan varian dari residual satu pengamatan ke pengamatan lain. Jika varian dari residual satu pengamatan ke pengamatan lain tetap, maka disebut homoskedastisitas dan jika berbeda disebut heteroskedastisitas. Model regresi yang baik adalah tidak terjadi heteroskedastisitas.

Hasil uji heteroskedastisitas pada penelitian ini dapat dilihat pada gambar di bawah ini

Gambar 2. Hasil Uji Heteroskedastisitas

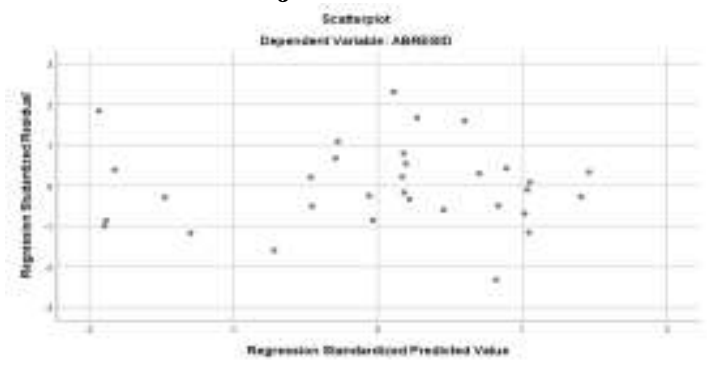

Berdasarkan gambar 2 tersebut, terlihat bahwa titik-titik tidak membentuk pola yang jelas dan menyebar secara acak (random) baik di atas maupun di bawah angka 0 pada sumbu Y. Dengan demikian, dapat disimpulkan bahwa model regresi yang digunakan tidak terjadi heterokesdastisitas.

\section{d. Hasil Uji Autokorelasi}

Menurut "Ghozali (2013:107-108), uji autokorelasi bertujuan menguji apakah dalam model regresi linear ada korelasi antara kesalahan pengganggu pada periode $t$ dengan kesalahan pengganggu pada periode $\mathrm{t}-1$ (sebelumnya)". Untuk mendeteksi ada atau tidaknya autokorelasi, dapat dilakukan uji statistik melalui uji Durbin- Watson (DW test). Model regresi yang baik adalah regresi yang bebas dari autokorelasi. Ketentuan uji autokorelasi dengan Durbin-Watson (DW) adalah sebagai berikut:

1) Jika DW < dL atau DW > 4-dL, berarti terdapat autokorelasi.

2) Jika DW terletak antara dU dan 4 - dU, berarti tidak ada autokorelasi.
3) Jika DW terletak antara dL dan dU atau antara 4 - dU dan 4 - dL, maka tidak menghasilkan kesimpulan yang pasti.

Tabel 3. Hasil Uji Autokorelasi

\begin{tabular}{|r|r|r|r|r|r|}
\hline & & & \multicolumn{1}{|c|}{ Model Summary } \\
Model & $\mathrm{R}$ & $\mathrm{R}$ Square & $\begin{array}{c}\text { Adjusted } \\
\text { R Square }\end{array}$ & $\begin{array}{r}\text { Std. Error of } \\
\text { the Estimate }\end{array}$ & $\begin{array}{r}\text { Durbin- } \\
\text { Watson }\end{array}$ \\
\hline 1 & .826 & .683 & .661 & .80286 & 1.028 \\
\hline
\end{tabular}

a. Predictors: (Constant), PER, ROE

b. Dependent Variable: HARGASAHAM

Berdasarkan tabel 3 tersebut, hasil analisis didapat nilai Durbin Watson sebesar 1,028 Sedangkan, $\mathrm{n}=32$ dan variabel independen berjumlah $2(\mathrm{~K}=2)$. Maka diperoleh nilai $\mathrm{dU}$ $=1,5736$ Nilai Durbin Watson $(\mathrm{DW})<$ dari dU $(1,028<1,5738)$ dan kurang dari ( 4 $\mathrm{dU})=4-1,5736=2,4264$. Sehingga dapat disimpulkan bahwa tidak terdapat autokorelasi pada pengujian ini.

\section{Hasil Analisis Regresi Linear Berganda}

Metode analisis regresi linier berganda yaitu suatu analisis yang digunakan untuk mengetahui apakah terdapat pengaruh yang signifikan dari satu variabel terikat (dependen) dan lebih dari satu variabel bebas (independen) (Gujarati, 2003:72). Hasil analisis regresi linear berganda pada penelitian ini dapat dilihat pada tabel berikut:

Tabel 4. Hasil Analisis Regresi Linear Berganda

\begin{tabular}{|c|c|c|c|c|c|c|}
\hline & & & efficient & & & \\
\hline & & $\begin{array}{l}\text { Unstan } \\
\text { Coef }\end{array}$ & $\begin{array}{l}\text { rdized } \\
\text { ents }\end{array}$ & $\begin{array}{c}\text { Standardize } \\
d \\
\text { Coefficients }\end{array}$ & & \\
\hline Model & & B & $\begin{array}{l}\text { Std. } \\
\text { Error }\end{array}$ & & $t$ & Sig. \\
\hline$\overline{1}$ & (Constant) & ,294 & ,863 & & ,341 & ,736 \\
\hline & ROE & 1,719 & ,270 & ,676 & 6,357 &, 000 \\
\hline & PER &, 813 & ,234 & ,370 & 3,480 & 002 \\
\hline
\end{tabular}

a. Dependent Variable: HARGA SAHAM

Berdasarkan tabel 4 tersebut ,hasil pengujian dari persamaan regresi tersebut dapat dijelaskan sebagai berikut:

$Y=\alpha+\beta_{1} X_{1}+\beta_{2} X_{2}+e$ 
$\mathrm{Y}=0,294+1,719 \mathrm{X}_{1}+0,813 \mathrm{X}_{2}+\mathrm{e}$

Dari persamaan regresi linier berganda diatas, dapat diketahui bahwa

1. Nilai konstanta $(\alpha)$ yang diperoleh sebesar 0,294 . Hal ini berarti bahwa jika variabel independen diasumsikan konstan, maka variabel dependen yaitu harga saham sebesar 0,294.

2. Koefisien variabel $R O E$ sebesar 1,719 yang artinya terdapat pengaruh positif variabel $R O E$ terhadap variabel harga saham dimana setiap kenaikan $1 \%$ ROE akan menaikkan harga saham sebesar 1,719 dengan asumsi variabel lainnya konstan.

3. Koefisien variabel PER sebesar 0,813 yang artinya terdapat pengaruh positif variabel $P E R$ terhadap variabel harga saham dimana setiap kenaikan $1 \%$ PER akan menaikkan harga saham sebesar 0,813 dengan asumsi variabel lainnya konstan.

\section{Hasil Uji Hipotesis Statistik}

\section{Hasil Uji Statistik t ( Uji Parsial )}

Uji $t$ digunakan untuk menguji variabel-variabel independen secara individu berpengaruh dominan dengan taraf signifikansi 5\%.. Berdasarkan tabel 5 tersebut, adapun hubungan variabel independen terhadap variabel dependen secara parsial dalam penelitian ini adalah sebagai berikut:

1) Uji hipotesis pengaruh $R O E$ terhadap harga saham Perusahaan Manufaktur sub sektor farmasi bahwa Variabel Return On Equity (ROE) dengan nilai $\mathrm{t}_{\text {hitung }} 6,357$ dan nilai koefisien $R O E$ menunjukkan angka positif dengan nilai signifikansi sebesar $0,000<0,05$. Sehingga dapat disimpulkan bahwa variabel Return On Equity (ROE berpengaruh signifikan terhadap Harga Saham.

2) Uji hipotesis pengaruh $P E R$ terhadap harga saham Perusahaan Manufaktur sub sektor Farmasi bahwa Variabel Price Earning Ratio (PER) dengan nilai $\mathrm{t}_{\text {hitung }} 3,480$ dan nilai koefisien $P E R$ menunjukkan angka positif dengan nilai signifikansi sebesar $0,002<0,05$. Sehingga dapat disimpulkan bahwa Price Earning Ratio (PER) berpengaruh signifikan terhadap Harga Saham.

\section{Hasil Uji Statistik F ( Uji Simultan )}

Uji F digunakan untuk menguji apakah variabel-variabel independen secara bersamasama berpengaruh signifikan terhadap variabel dependen (Ghozali,2011). Tabel 6 menunjukkan Uji Statistik $F$ yang dapat dilihat berikut ini :

Tabel 5. Hasil Uji Statistik F

\begin{tabular}{|l|l|r|r|r|r|c|}
\hline \multicolumn{7}{|c|}{ ANOVA $^{\text {a }}$} \\
\hline \multirow{2}{*}{ Model } & $\begin{array}{c}\text { Sum of } \\
\text { Squares }\end{array}$ & \multicolumn{1}{c|}{ df } & $\begin{array}{c}\text { Mean } \\
\text { Square }\end{array}$ & F & Sig. \\
\hline \multirow{2}{*}{1} & Regression & 40,220 & 2 & 20,110 & 31,199 &, $000^{\circ}$ \\
\cline { 2 - 7 } & Residual & 18,693 & 29 &, 645 & & \\
\cline { 2 - 7 } & Total & 58,913 & 31 & & & \\
\hline
\end{tabular}

a. Dependent Variable: HARGA SAHAM

b. Predictors: (Constant), PER, ROE

Berdasarkan tabel 5 tersebut, dapat diketahui bahwa secara simultan variabel independen memiliki pengaruh yang signifikan terhadap variabel dependen. Hal ini dapat dibuktikan dari nilai $F_{\text {hitung }}$ 31,199 dan nilai signifikansi (sig.) sebesar $0,000<0,05$. Dengan demikian, dapat dikatakan bahwa Return On Equity (ROE) dan Price Earning Ratio (PER) secara simultan berpengaruh signifikan terhadap harga saham pada perusahaan manufaktur sub sektor Farmasi di Bursa Efek Indonesia.

\section{Hasil Koefisien Determinasi ( $\mathbf{R}^{\mathbf{2}}$ )}

Menurut Ghozali (2013:95), Koefisien determinasi pada intinya mengukur seberapa jauh kemampuan model dalam menerangkan variasi variabel dependen. Nilai determinasi ditentukan dengan nilai Adjusted R Square.

Tabel 6. Hasil Koefisien Determinasi ( $\mathbf{R}^{2}$ )

\begin{tabular}{|c|c|c|c|c|}
\hline \multirow[b]{2}{*}{ Model } & \multicolumn{3}{|c|}{ Model Summary } & \multirow[b]{2}{*}{$\begin{array}{l}\text { Std. Error of } \\
\text { the Estimate }\end{array}$} \\
\hline & $\mathrm{R}$ & $\begin{array}{c}\mathrm{R} \\
\text { Square }\end{array}$ & $\begin{array}{l}\text { Adjusted } \\
\text { R Square }\end{array}$ & \\
\hline 1 &, $826^{\mathrm{a}}$ &, 683 & ,661 &, 80286 \\
\hline
\end{tabular}

Berdasarkan tabel 6 tersebut, didapatkan nilai Adjusted $R$ Square sebesar 0,661 atau sebesar 66,10 \%. Sehingga dapat disimpulkan, bahwa harga saham dipengaruhi oleh variabel $R O E$ dan PER sebesar 66,10\%. Sedangkan, sisanya sebesar 33,90\% dijelaskan oleh faktor-faktor lain yang tidak diteliti dalam penelitian ini. 


\section{Pembahasan dan Interpretasi}

Penelitian ini bertujuan untuk menguji pengaruh Return On Equity (ROE) dan Price Earning Ratio (PER) terhadap harga saham Perusahaan Manufaktursub sektor Farmasi di Bursa Efek Indonesia (BEI) .Berikut ini adalah pembahasan hasil penelitian yang telah dilakukan.

\section{a. Pengaruh Return On Equity (ROE) secara parsial terhadap Harga Saham \\ Return On Equity (ROE) memiliki} pengaruh positif dan signifikan terhadap perubahan harga saham perusahaan farmasi (hasil uji t). Hasil ini memberikan indikasi bahwa $R O E$ merupakan indikator yang sangat penting bagi investor untuk mengetahui keuntungan yang diperoleh dari investasi yang ditanamkan pada saham perusahaan farmasi. Semakin tinggi $R O E$ berarti semakin efisien penggunaan modal sendiri yang dilakukan oleh pihak manajemen perusahaan farmasi untuk menghasilkan keuntungan bagi pemegang saham. Kenaikan ROE menandakan meningkatnya kinerja manajemen dalam mengelola sumber dana yang ada untuk menghasilkan laba dan nilai $R O E$ akan meningkat sehingga para investor tertarik membeli saham tersebut sehingga harga saham perusahaan tersebut akan mengalami kenaikan. Hasil penelitian ini sejalan dengan teori yang dikemukakan oleh Harahap (2010 : 156 ) semakin besar ROE semakin besar pula harga saham karena besarnya $R O E$ memberikan indikasi bahwa pengembalian investor akan tertarik untuk membeli saham tersebut dan hal itu menyebabkan harga pasar saham cenderung naik. Dan didukung juga oleh penelitian terdahulu yang dilakukan oleh Dinda Alfianti Aldini (2018 ) yang menyimpulkan bahwa ROE berpengaruh positif dan signifikan terhadap harga saham.

\section{b. Pengaruh Price Earning Ratio (PER) secara parsial terhadap Harga Saham \\ Price Earning Ratio (PER)}

mempunyai pengaruh positif terhadap harga saham perusahaan farmasi (hasil uji $\mathrm{t}$ ). PengaruhPriceEarningRatio(PER)yangpositif berbandinglurusdenganhargasaham. Halinime ngindikasikanbahwaapabilaPERmengalamipe ningkatanmakahargasahamakanmengalamipe ningkatandansebaliknya.Dalam penelitian ini, nilai koefisien menunjukkan angka positif. Hasil inimemberikan indikasi bahwa investor dalam melakukan investasi memperhatikan PER sebagai salah satu pertimbangan dalam mengambil keputusan investasinya karenadengan meningkatnya $P E R$, investor mengharapkan adanya pertumbuhan perusahaanyang lebih tinggi dengan harapan memperoleh pengembalian dari hasil investasi. Nilai PER yang tinggi menunjukkan ekspektasi investor tentang prestasi perusahaan di masayang akan datang cukup tinggi.Hasil ini sejalan dengan teori yang dikemukakan oleh Malintan (2011), yang menyatakan "semakin tinggi $P E R$ menunjukkan prospektus harga saham dinilai semakin tinggi oleh investor terhadap pendapatan per lembar sahamnya, sehingga $P E R$ yang semakin tinggi juga menunjukkan semakin mahal saham tersebut terhadap pendapatannya. Jika harga saham semakin tinggi maka selisih harga saham periode sekarang dengan periode sebelumnya semakin besar, sehingga capital gain juga semakin meningkat yang menyebabkan meningkatnya return saham".

Hasil penelitian ini sejalan dengan penelitian sebelumnya yang dilakukan oleh Dedi Suselo (2015) yang menunjukkan bahwa variabel $P E R$ berpengaruh positif dan signifikan terhadap harga saham. Sejalan juga dengan penelitian Siti Rahmania Natsir (2016) yang menunjukkan bahwa variabel PER berpengaruh positif dan signifikan terhadap harga saham.

c. Pengaruh Return On Equity (ROE) dan Price Earning Ratio (PER) secara simultan terhadap Harga Saham

Return On Equity (ROE) dan Price Earning Ratio (PER) secara simultan berpengaruh signifikan terhadap harga saham perusahaan (hasil uji F). Dari hasil analisis regresi dilihat bahwa secara simultan variabel independen memiliki pengaruh yang signifikan terhadap variabel dependen. Hal ini memberikan indikasi dalam menilai saham yang tercermin dalam harga saham perusahaan farmasi, investor dapat menganalisa dan sebagai bahan pertimbangan dalam pengambilan keputusan investasi. 
Hasil penelitian ini sejalan dengan penelitian sebelumnya yang dilakukan oleh Pande Wydia Rahmadewi (2018) yang menunjukkan bahwa variabel ROE dan PER secara simultan berpengaruh secara signifikan terhadap Harga Saham. Demikian juga sejalan dengan penelitian Arison Nainggolan (2017) bahwa variabel ROE dan PER secara bersam-sama berpengaruh secara signifikan terhadap Harga Saham.

\section{SIMPULAN DAN SARAN Simpulan}

Berdasarkan hasil analisis data dalam penelitian ini, maka dapat disimpulkan bahwa :

1. Return on Equity (ROE) secara parsial berpengaruh positif dan signifikan terhadap harga saham pada perusahaan manufaktur sub sektor Farmasi di Bursa Efek Indonesia (BEI) dengan nilai signifikansi sebesar $0,000<0,05$.

2. Price Earning Ratio (PER) secara parsial berpengaruh positif dan signifikan terhadap harga saham pada perusahaan manufaktur sub sektor Farmasi di Bursa Efek Indonesia (BEI) dengan nilai signifikansi $0,002<0,05$.

3. Return on Equity (ROE) dan Price Earning Ratio (PER) secara simultan berpengaruh signifikan terhadap harga saham pada perusahaan manufaktur sub sektor Farmasi di Bursa Efek Indonesia(BEI) dengan nilai signifikansi $0,000<0,05$.

4. Koefisien Determinasi $\left(R^{2}\right)$ diperoleh angka sebesar 66,10\%, Sehingga dapat disimpulkan, bahwa harga saham dipengaruhi oleh variabel $R O E$ dan PER sebesar 66,10\%. Sedangkan, sisanya sebesar 33,90\% dijelaskan oleh faktorfaktor lain yang tidak diteliti dalam penelitian ini.

\section{Saran}

Berdasarkan hasil penelitian dan kesimpulan yang telah dipaparkan sebelumnya, adapun saran yang dapat diberikan adalah sebagai berikut:

1. Bagi Investor, sebagai bahan pertimbangan untuk menanamkan investasi pada bidangsaham dengan memperhatikan pergerakan harga saham, karena harga saham menunjukkan prestasi emiten, apabila emiten mempunyai prestasi yang semakin baik maka keuntungan yang diperoleh dari operasi usaha semakin besar. Harga saham juga menunjukkan nilai suatu perusahaan dan merupakan indeks yang tepat untuk efektifitas perusahan.

2. Bagi Peneliti lebih lanjut, dilihat dari nilai koefisien determinasi dalam penelitian iniadalah sebesar 0,661 yang berarti bahwa harga saham dipengaruhi oleh variabel $R O E$ dan PER sebesar 66,10\%. Sedangkan, sisanya sebesar $33,90 \%$ dijelaskan oleh faktor-faktor lain yang tidak diteliti dalam penelitian ini. Untuk itu perlu adanya penelitian lebih lanjut mengenai faktor-faktor lainnya yang mempengaruhi harga saham seperti inflasi, tingkat bunga, kurs valas, kebijakan pemerintah, dan sebagainya. Selain itu, penelitian selanjutnya dapat memperluas objek penelitian dengan interval waktu yang lebih panjang.

\section{E. DAFTAR RUJUKAN}

Amanda, Astrid. 2013. Pengaruh Debt to Equity Ratio, Return on Equity, Earning per Share, dan Price Earning Ratio Terhadap Harga Saham (Studi pada perusahaan Food and Beverages yang Terdaftar di BEI Tahun 20082011. Jurnal Administrasi Bisnis Vol. 4 No. 2.

Alfianti, Dinda, dkk. 2018. Pengaruh Profitabilitas Terhadap Harga Saham Pada Perusahaan Makanan dan Minuman yang terdaftar di Bursa Efek Indonesia. Jurnal Bisnis Indonesia 8 (1).

Arikunto, Suharsimi. 2010. Prosedur Penelitian Suatu Pendekatan Praktik. Edisi :

Revisi VI. Jakarta : PT. Rineka Cipta.

Brigham, F. Eugene dan Houston, Joel F. 2010. Dasar dasar Manajemen Keuangan. Buku 1 (Edisi 11). Jakarta: Salemba Empat.

Bursa Efek Indonesia. 2021. Laporan Keuangan dalam bentuk Annual Report tahun 2015- 2018. Diakses melalui http://www.idx.co.id. 
Carlo, Michael Aldo. 2014. Pengaruh Return On Equity, Dividend Payout Ratio, dan Price to Earning Ratio pada Return Saham. E- Jurnal Akuntansi Universitas Udayana. 7.1. ISSN : 23028556.

Darmadji, T dan Fakhrudin M.H. 2012. Pasar Modal di Indonesia Pendekatan Tanya Jawab. Jakarta: Salemba Empat.

Fahmi, Irham. 2012. Manajemen Keuangan Perusahaan dan Pasar Modal. Bandung. Penerbit : Mitra Wacana Media.

Ghozali, Imam. 2013.Aplikasi Analisis Multivariete dengan Program IBM SPSS.Semarang:Badan Penerbit Universitas Diponegoro.

, 2013. Aplikasi Analisis Multivariete dengan Program. Semarang:

Badan Penerbit Universitas Diponegoro.

Gujarati, Damodar. 2003. Basic Econometrics. New York : Mc. Graw Hill.

Hanafi, Mahduh dan A. Halim. 2007. Analisis Laporan Keuangan. Edisi : 3. Yogyakarta.

Harahap, Sofyan. Safri. 2010. Analisis Kritis Laporan Keuangan. Jakarta : PT. Raja Grafindo Persada.

Husnan, Suad. 2008. Dasar-Dasar Teori Portofolio Dan Analisis Sekuritas. EdisiKelima, Yogyakarta: BPFE.

Ircham, Muhammad. 2014. Pengaruh Struktur Modal dan Profitabilitas TerhadapHarga Saham (Studi pada Perusahaan Makanan dan Minuman yangTerdaftar di Bursa Efek Indonesia Tahun 2009-2012). Jurnal AdministrasiBisnis Vol. 11 No. 1.

Jogiyanto, H. 2010. Teori Portofolio dan Analisis Investasi. Edisi Kesembilan.BPEF. Yogyakarta.

Kasmir. 2018. Analisis Laporan Keuangan. Edisi 1. Cetakan ke- 11 Jakarta: Penerbit PT. Raja Grafindo Persada.

Malintan, Rio. 2011. Pengaruh Current Ratio $(C R)$, Debt to Equity Ratio, PriceEarning Ratio (PER), dan Return On Assets (ROA) Terhadap ReturnSaham. Jurnal Ilmiah Mahasiswa FEB. http://JIMFEBUB.AC.ID.
Munawir. 2002. Analisis Laporan Keuangan. Yogyakarta: Liberty.

Nainggolan, Arison, 2019. Pengaruh EPS, ROE,NPM,DER,PER terhadap Harga Saham pada Perusahaan Perbankan yang terdaftar di Bursa Efek Indonesia Periode 2014 - 2017. Jurnal Manajemen 5 (1).

Natsir, Siti Rahmania.2016.Pengaruh Return On Assets (ROA), Return On Equity (ROE) dan Price Earning Ratio (PER)terhadap Harga Saham Pada Perusahaan Perbankan yang Terdaftar di Bursa Efek Indonesia. Universitas Islam Negeri Alaudidin Makasar

Prihatina, Yani dkk. 2012. Pengaruh Earning Per Share, Price Earning Ratio, Economic Value Added, dan Risiko Sistematik terhadap Return Saham (Studi Pada Perusahaan Real Estate dan Property yang terdaftar di Bursa Efek Indonesia Periode 2007-2009). Universitas Syiah Kuala, Banda Aceh.

Rarti, Teska Destia. 2015. Pengaruh Kinerja Keuangan terhadap Harga Saham Perusahaan Tekstil dan Produk Tekstil (TPT) yang Terdaftar di Bursa Efek Indonesia. Skripsi. Fakultas Ekonomi Universitas Negeri Yogyakarta.

Sanusi, Anwar. 2011. Metodologi Penelitian Bisnis. Cetakan Ke-3. Jakarta: Salemba Empat.

Susilo, Dedi dkk,2015. Pengaruh Variabel Fundamental dan makro Ekonomi Terhadap Harga Saham (Studi pada Perusahaan yang masuk dalam Indeks LQ45. Jurnal Aplikasi Manajemen13(1)

Sugiyono. 2009. Metode Penelitian Bisnis (Pendekatan Kuantitatif, Kualitatif,dan $R \& D)$. Bandung : Alfabeta.

Sutrisno. 2012. Manajemen Keuangan Teori, Konsep, dan Aplikasi. Penerbit: Ekonisia,Kampus Fakultas Ekonomi UII, Jakarta.

Tandelilin, Eduardus. 2010. Portofolio dan Investasi: Teori dan Aplikasi.Yogyakarta: Kanisius.

Wibowo, Riswandha Adi. 2014. Pengaruh Working Capital Turnover, Long-Term Debt to Equity Ratio, dan Return On Equity Terhadap ReturnSaham. 
Jurnal Kompetitif, Vol. 10, No. 2, hal. 34 - 44, Juli - Desember 2021

p-ISSN 2302-4585; e-ISSN 2721-3765

http://ejournal-

sl.undip.ac.id/index.php/accounting,

Vol.3 No.3. Tahun 2014. ISSN : 23373806.

Zuliarni, Sri. 2012. Pengaruh Kinerja Keuangan Terhadap Harga Saham Pada Perusahaan Mining And Mining Service Di Bursa Efek Indonesia (BEI). Pekanbaru. Penerbit : Universitas Riau. Jurnal Aplikasi Bisnis. Vol.3 No.1.Oktober, hal $36-48$. 